\title{
Integration of Solar Power Plant in Distribution Network
}

\author{
Srete N. Nikolovski, Predrag Ž. Marić, Ljubomir V. Majdandžić \\ Departement of Power Engineering, Faculty of Electical Engineering, Josip Juraj Strossmyer University of Osijek, \\ Osijek, Croatia
}

\begin{tabular}{|c|c|}
\hline Article Info & ABSTRACT \\
\hline Article history: & This paper presents the integration of the solar power plant SE Gumiimpex, \\
\hline Received Apr 4, 2015 & $\begin{array}{l}\text { rated power of } 1 \mathrm{MW} \text { in Croatian distribution network. Basic data of solar } \\
\text { power plant are presented as well as the analysis of its impact on the }\end{array}$ \\
\hline Revised May 11, 2015 & distribution network. Power quality measurements, seven days before and \\
\hline Accepted May 29, 2015 & $\begin{array}{l}\text { seven days after the connection of PV plant to the network are performed and } \\
\text { obtained power quality indices are compared to those stated in the power }\end{array}$ \\
\hline Keyword: & $\begin{array}{l}\text { quality standard HRN EN } 50160 / 2012 \text { and Croatian national grid code. There } \\
\text { are also presented results of the simulation of protection relays selection, } \\
\text { setting and coordination. }\end{array}$ \\
\hline
\end{tabular}

Power quality

Protection coordination

Short circuit calculation

Solar power plant

Copyright (c) 2015 Institute of Advanced Engineering and Science. All rights reserved.

\section{Corresponding Author:}

Srete Nikolovski,

Department of Power Engineering,

Faculty of Electrical Engineering, Josip Juraj Strossmyer University of Osijek

K. Trpimira 2B, 31000 Osijek, Croatia.

Email: srete.nikolovski@etfos.hr

\section{INTRODUCTION}

In order to reach the limit of $20 \%$ of electricity generated from renewable energy sources, Croatian government has decided to introduce a system of incentive for renewable energy sources. The above mentioned incentives have caused an increased interest from investors to build solar power plants (installed power from $10 \mathrm{~kW}$ to $1 \mathrm{MW}$ ). According to public available data from Croatian Energy Market OperatorHROTE, total installed capacities of PV plants in Croatia are 37.6 MW (on 31.12.2014) [5]. The first large solar installation (1 MW) in Croatia was SE Kanfanar and second is SE Gumiimpex in town Varaždin, which is analyzed in this paper. HROTE and the investor conclude contract for the purchase of electricity produced from PV power plant. The price of electricity is determined by the regulated feed-in tariffs that include incentives. In order to obtain such a contract, investor is obliged to make, among other things, three technical studies. The problem from investors is to satisfy demands given by Croatian national grid company for these studies and this paper gives procedure and technical solutions for investors. The first is the "Study of the optimal technical solution of PV plant connection to the distribution network", the second is the "Study of the impact of PV plant on the power quality indices on the distribution network and the third is the "Study of the protection settings and coordination of PV power plant and the distribution network".

The first study deals with the best variant of PV power plant connection to the network and it contains power flow calculation, voltage drops analysis, voltage stability analysis as well as the N-1 security analysis [1]. Above mentioned analyzes are carried out for both the maximum and minimum load in the distribution network. The second study includes calculation and measurement of power quality parameters, seven days before and seven days after the connection of the PV power plant to the network [2]. The results should be in accordance with European Croatian) standard EN (HRN) 50160:2012 as well as with the Croatian national grid code. The Study of the protection relays settings and coordination is very important for distribution network and PV power plant security and reliability [3]. 


\section{TECHNICAL DATA OF PV POWER PLANT}

Solar power plant Gumiimpex is built on the roof of the existing building and covers an area of approx. $7530 \mathrm{~m}^{2}$ and consists of 4564 photovoltaic modules attached to an aluminium frame. The total power of photovoltaic modules is $1141 \mathrm{~kW}$, and the total power of 67 three-phase inverters is $999 \mathrm{~kW}$. Photovoltaic modules are connected in series to form strings. Considering the number of series-connected modules, there are four types of strings: 24 modules in one string, 23 modules in one string, 22 modules in one string and 21 modules in one string. Polycrystalline photovoltaic modules Solvis SV60-250 are used. Every PV module is consist of 60 cells and total rated power of module is $250 \mathrm{~W}$. Dimensions of the module are $1663 \mathrm{~mm} \mathrm{x}$ $998 \mathrm{~mm} \times 35 \mathrm{~mm}$ and total module weight is $21.5 \mathrm{~kg}$. Basic data about PV module are presented in Table I.

Table 1. The Photovoltaic Modlue Data

\begin{tabular}{ccc}
\hline Module type & $\begin{array}{c}\text { Solvis } \\
\text { SV60-150 }\end{array}$ & Rating values \\
\hline Power & & $250 \mathrm{~W}$ \\
Open circuit & $37,6 \mathrm{~V}$ \\
voltage & \\
Short circuit & $8,67 \mathrm{~A}$ \\
current & $30.5 \mathrm{~V}$ \\
Rated voltage & $680 \mu \mathrm{H}$ \\
Rated current & & \\
\hline
\end{tabular}

Single line diagram of PV power plant and utility TS 110/20 kV substation, $20 \mathrm{kV}$ distribution networkan PV power plant is shown in Figure 1. The connection of PV power plant is with TS 20/0.4 kV.

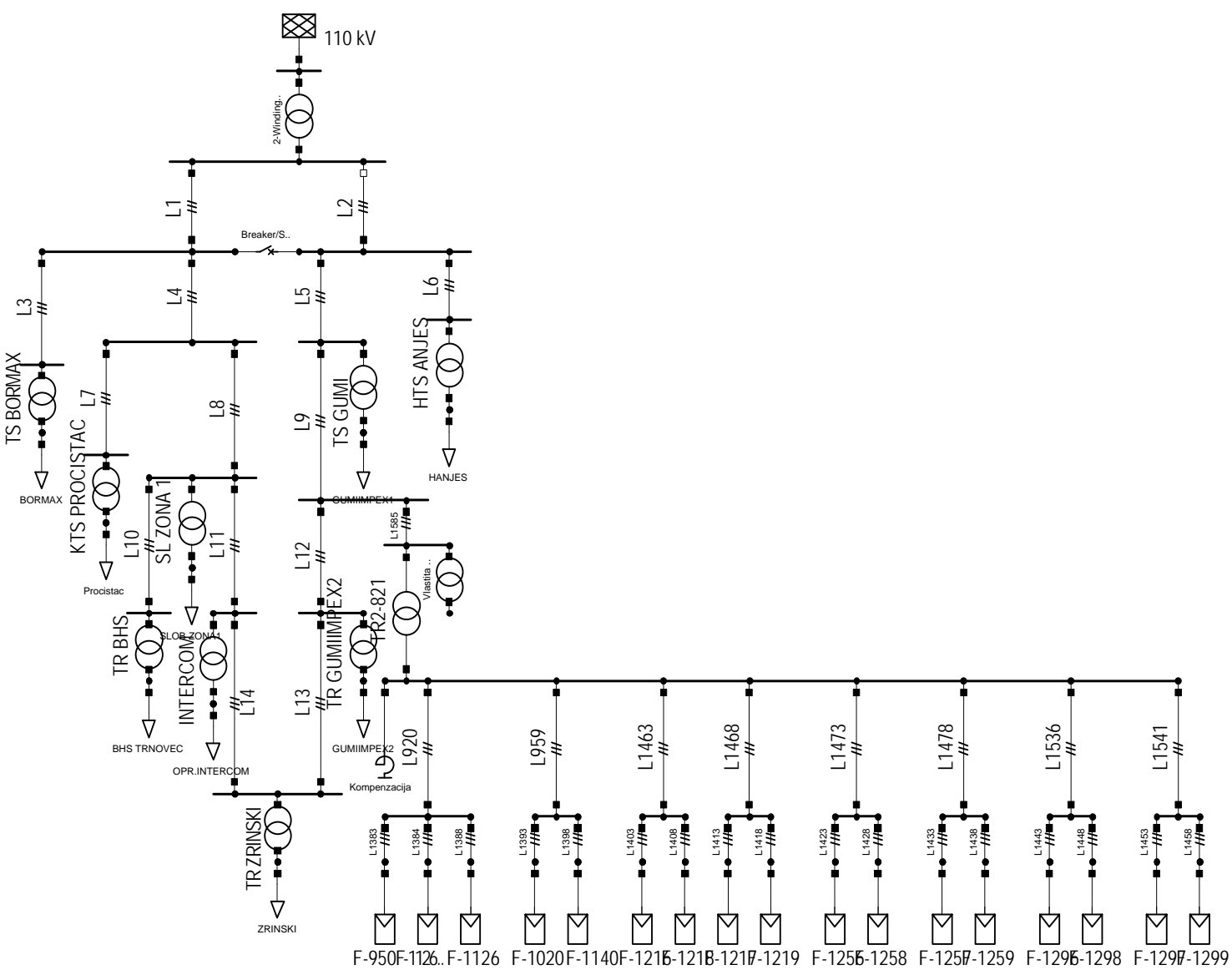

Figure 1. Single line diagram of PV plant and distribution network 


\section{POWER QUALITY INDICES}

Limits on the values of some voltage quality parameters specified by Croatian national grid code, are shown in Table 2.

Table 2. Limits on the values of voltage quality parameters

\begin{tabular}{|c|c|c|}
\hline Parameter & Limit values & Remarks \\
\hline Frequency & $49.95-50.05 \mathrm{~Hz}$ & $\begin{array}{c}\text { standard (normal) operational } \\
\text { conditions }\end{array}$ \\
\hline Voltage violations & $\mathrm{Un} \pm 10 \%$ & $\begin{array}{l}95 \% \text { of the time, } 10 \text { - minutes average } \\
\text { measured values }\end{array}$ \\
\hline Voltage unbalance & $\leq 1.3 \% \mathrm{Un}$ & $\begin{array}{l}95 \% \text { of the time, } 10 \text { - minutes average } \\
\text { measured values }\end{array}$ \\
\hline $\begin{array}{l}\text { Voltage harmonic } \\
\text { distortion }\end{array}$ & $\mathrm{THD} \leq 2.0 \%$ & $\begin{array}{l}95 \% \text { of the time, } 10 \text { - minutes average } \\
\text { measured values }\end{array}$ \\
\hline
\end{tabular}

According to the Croatian national grid code, power quality measurements are performed at the $\mathrm{CCP}$ point of PV power plant connection to the network. In this sample case this point is $20 \mathrm{kV}$ bus in substation 20/0.4 kV). Power quality measurements before and after connecting the PV power plant to the network was performed with three phase power quality analyzer Fluke 435. Used instrument is in class A. In this paper only some power quality parameters that were measured after connecting the solar power plants to the network are shown. Figure 3 shows 10-minutes average RMS values of voltage after the PV power plant is connected. As can be seen from the Figure 3, the limit of $\pm 10 \%$ of rated voltage is not exceeded. [6]

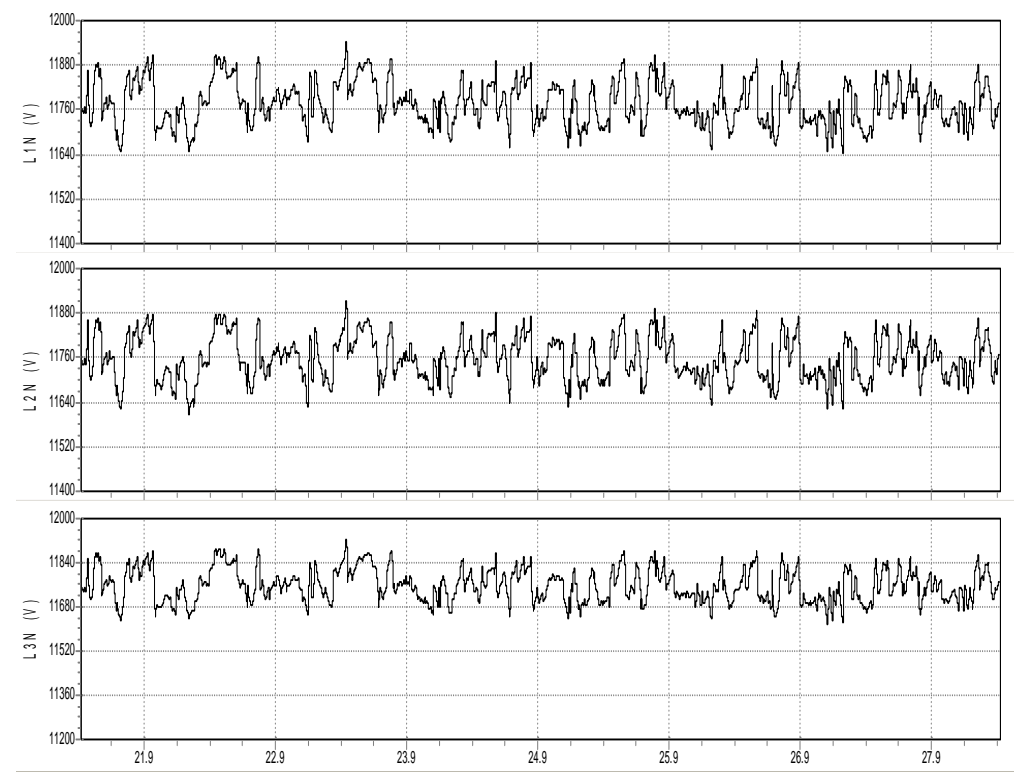

Figure 2. 10-minutes average RMS values of phase voltages

Figure 3 shows measured frequency after the PV power plant is connected 


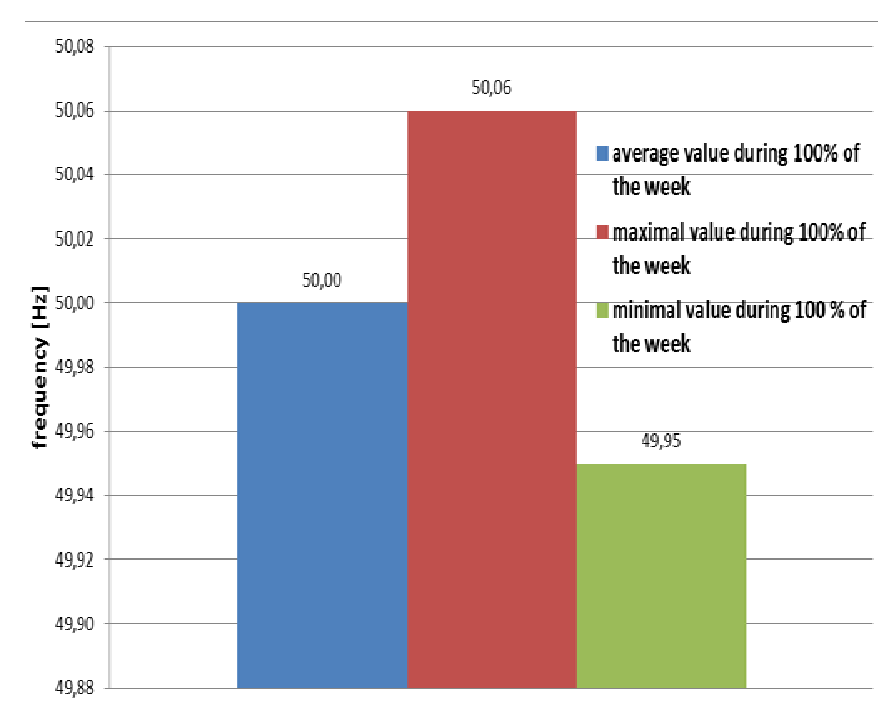

Figure 3. Measured frequency after the connection of PV power plant

A frequency vale is under the permissible limits. Figure 4 shows measured harmonic distortion (total harmonic distortion - THD) after the PV power plant is connected. As can be seen from the Figure 5, the value of voltage THD is throughout the entire period of measurement smaller than the limit value of $2 \%$. It should be noted that the Croatian national grid code is regarding harmonic distortion more restrictive than the standard HRN EN 50160/2013. The limit value for voltage THD stated in grid code is $2 \%$ whereas in standard EN 50160 it is $8 \%$.

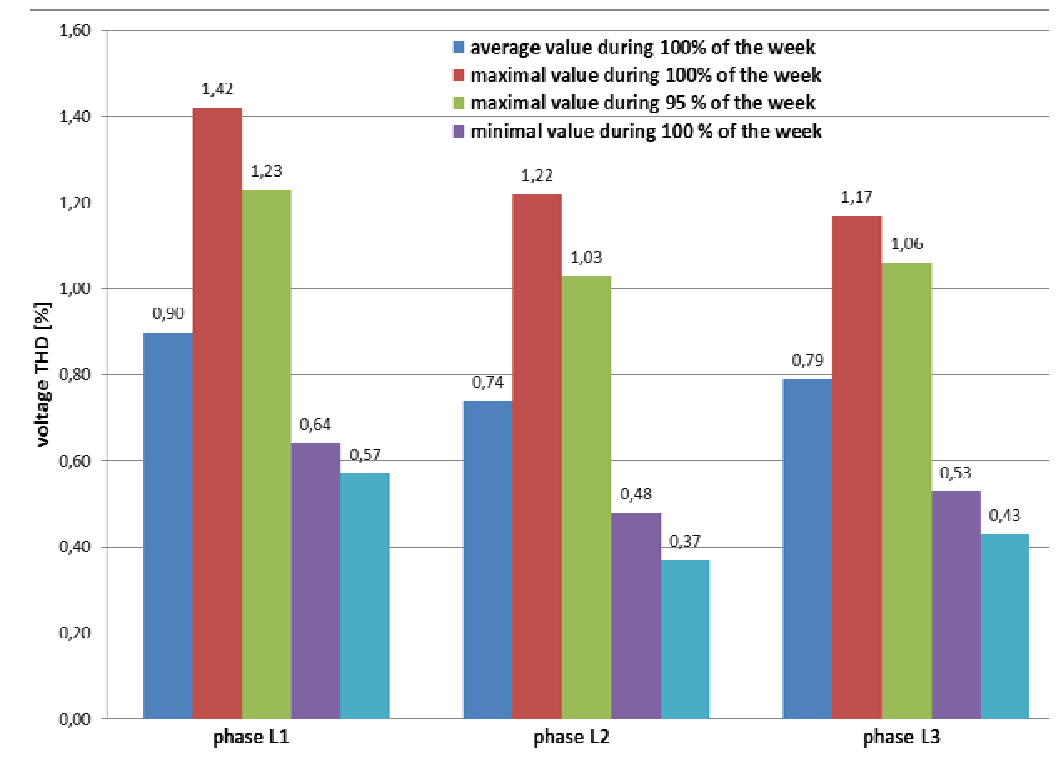

Figure 4. Measured voltage harmonic distortion

Figure 5 shows voltage unbalance during measured week after the PV plant is connected. As can be seen from the Figure 6, the range of measured voltage unbalance is $0.08 \%-0.18 \%$ which is within the allowable limits. Based on the performed power quality measurements it can be concluded that PV power plant does not distort the power quality of supply voltage because all measured power quality parameters are within the limits that are imposed by the Croatian national grid code and standard HRN EN 50160/2012. 


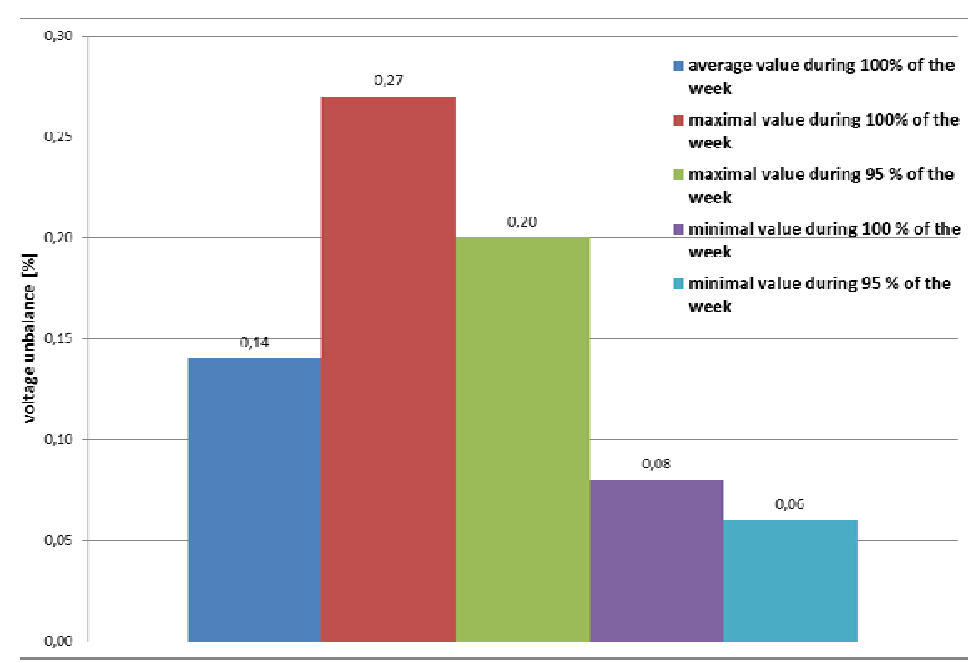

Figure 5. Voltage unbalance after the connection of PV power plant

\section{RELAY PROTECTION COORDINATION}

The study of the protection settings and coordination, seventeen different places and types of short circuit simulation were performed according the Croatian HEP DSO recommendation. Due to lack of space, in this paper only three cases of short circuit simulation will be presented:

- $\mathrm{SC} 1$ - three phase short circuit at a remote location (relative to the PV power plant) on the $20 \mathrm{kV}$ feeder

- SC2 - two phase short circuit at the $20 \mathrm{kV}$ bus in substation 20/0.4 TS Gumiimpex

- SC3 - single line to ground short circuit at the $0.4 \mathrm{kV}$ bus in substation 20/0.4 TS Gumiimpex

- SC4 - single line to ground short circuit at the terminals of one of the inverters in PV plant

Protection relays coordination was performed using software [7]. SC1 - three phase short circuit at a remote location. Simulation starts at time $t=0$ and short circuit occurs at time $t=100 \mathrm{~ms}$. Type of simulated short circuit is balanced three phase fault with fault impedance $=0 \Omega$. The location of fault is on the $20 \mathrm{kV}$ line close to substation TS $110 / 20 \mathrm{kV}$. Figure 7 shows the RMS values of currents those inverters of PV power plant feeds into the distribution network during a short circuit simulation.

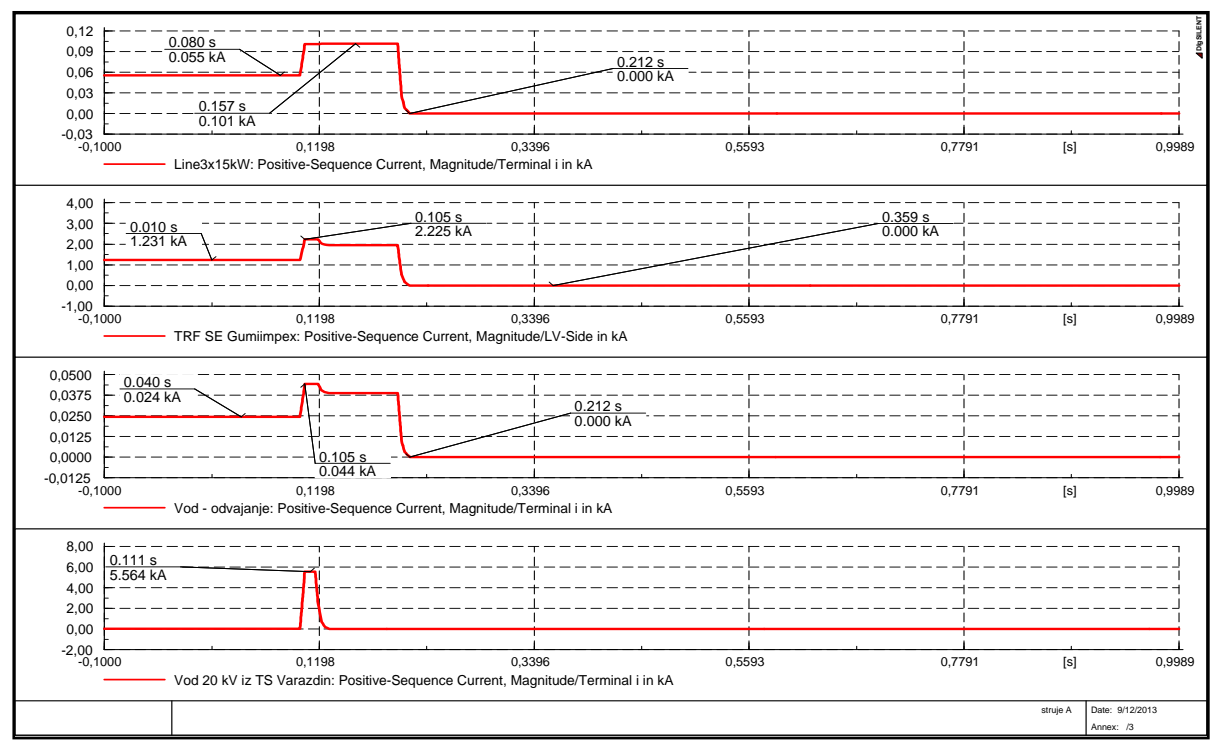

Figure 7. RMS values of currents during short circuit simulation for case SC1

Diagram on the Figure 6 shows current of one group of inverters (there are totally eight groups of inverters in PV power plant) at the point where PV power plant is connected to the network $(0.4 \mathrm{kV}$ side of 
the transformer Gumiimpex 20/0.4 kV). The second diagram shows total current that PV plant feeds to the network at the $0.4 \mathrm{kV}$ side of the transformer Gumiimpex $20 / 0.4 \mathrm{kV}$. The third diagram shows total current that PV plant feeds to the network at the $20 \mathrm{kV}$ side of the transformer Gumiimpex $20 / 0.4 \mathrm{kV}$. And the last diagram shows the current at the beginning of the affected line (in the $110 / 20 \mathrm{kV}$ transformer station Varaždin). Short-circuit protection (overcurrent relay) located at the beginning of the affected line (in the substation $110 / 20 \mathrm{kV}$ Varaždin) tripped at time $\mathrm{t}=115 \mathrm{~ms}$. At the same time, short circuit protection at the affected line end (20 kV switchboard) also tripped and faulted $20 \mathrm{kV}$ line is disconnected. Under voltage protection $(\mathrm{V}<<)$ of the inverters in PV power plants is activated at time $\mathrm{t}=197 \mathrm{~ms}$ so that PV power plant is prevented to operate as an isolated system. Overcurrent protection (I>) in relay located at the $20 \mathrm{kV}$ side of Gumiimpex 20/0.4 kV transformer station serve as a backup to under voltage protection of the PV power plant. Figure 8 shows the single line diagram with marked breakers that tripped
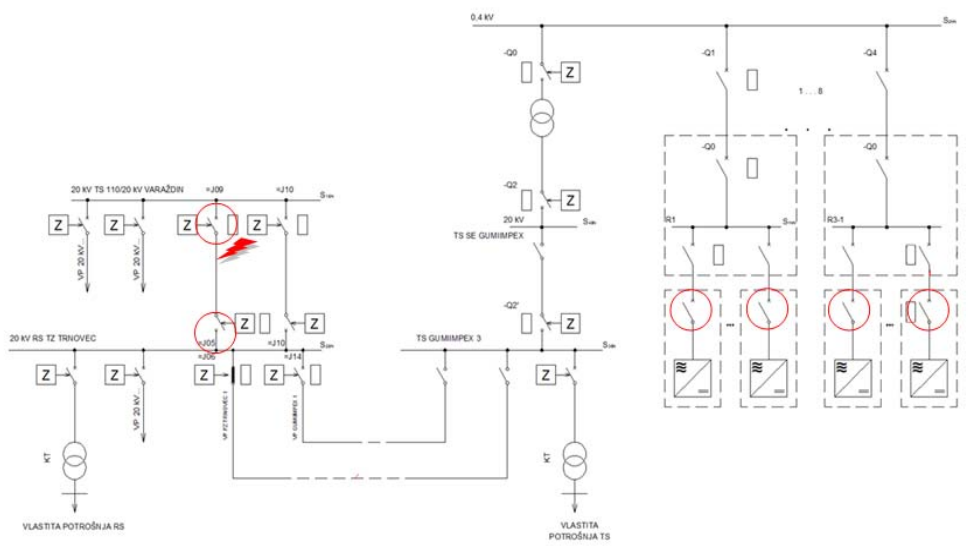

Figure 8. Tripped protection devices for case SC1

Figure 9 shows the RMS values of voltages at the three locations close to PV power plant during a short circuit simulation. Upper diagram on the Figure 8 shows voltage at the inverters terminals. The second diagram shows the voltage at the $0.4 \mathrm{kV}$ side of the transformer Gumiimpex $20 / 0.4 \mathrm{kV}$. The last diagram shows voltage at the $20 \mathrm{kV}$ side of the transformer Gumiimpex $20 / 0.4 \mathrm{kV}$.

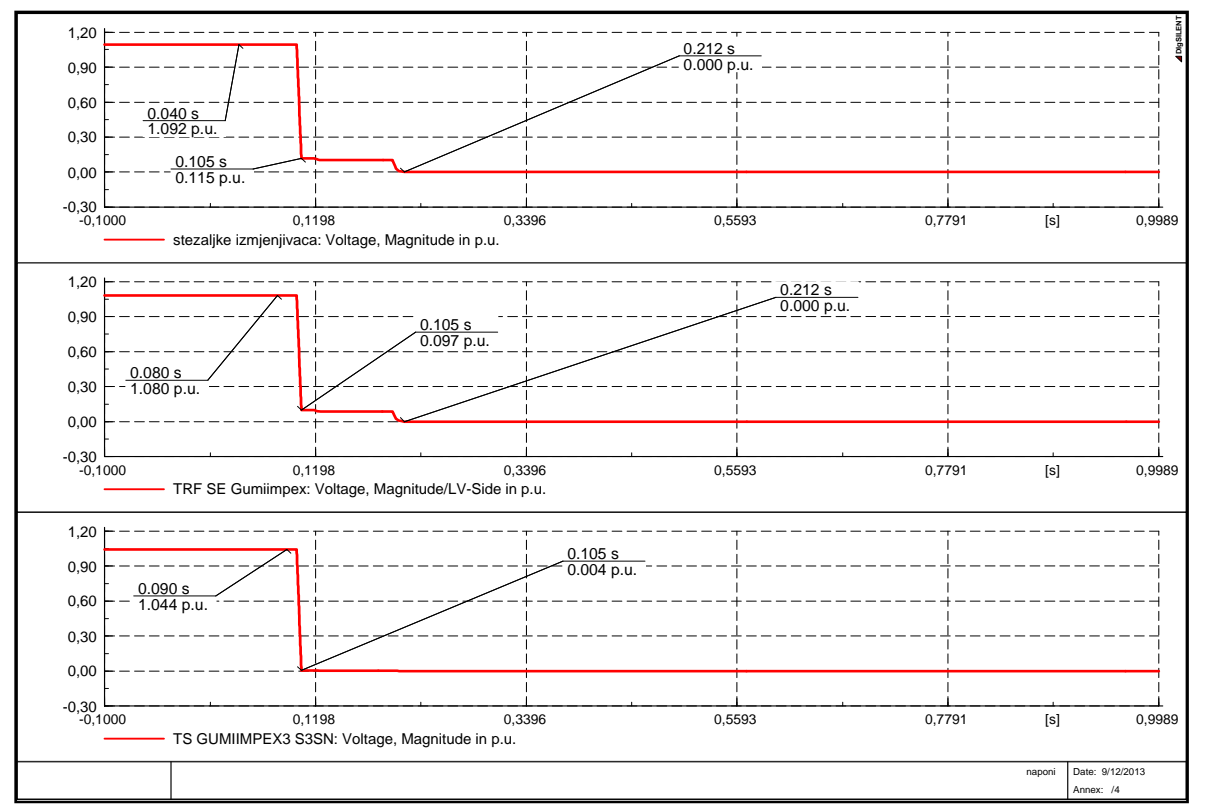

Figure 9. RMS values of voltages during short circuit simulation for case SC1 
SC28 - two phase short circuit at the $20 \mathrm{kV}$ bus in substation 20/0.4 TS Gumiimpex. Simulation starts at time $t=0$ and short circuit occurs at time $t=100 \mathrm{~ms}$. Type of simulated short circuit is two phase fault with fault impedance $=0 \Omega$. The location of fault is on the $20 \mathrm{kV}$ bus of the transformer Gumiimpex 20/04 kV (this transformer connects PV power plant with the network). Figure 10 shows the RMS values of currents which inverters of PV power plant feeds into the distribution network during a short circuit simulation. Upper diagram on the Figure 10 shows current of one group of inverters at the point where PV power plant is connected to the network $(0.4 \mathrm{kV}$ side of the transformer Gumiimpex $20 / 0.4 \mathrm{kV})$. The second diagram shows total current that PV plant feeds to the network at the $0.4 \mathrm{kV}$ side of the transformer Gumiimpex 20/0.4 kV. The third diagram shows current at the end (close to TS Gumiipex) of the $20 \mathrm{kV}$ line which connects substation Gumiimpex with rest of the distribution system. The forth diagram shows the current at the beginning of the $20 \mathrm{kV}$ line in transformer station Varaždin $110 / 20 \mathrm{kV}$ (this transformer station is connecting distribution system with the transmission system). The last diagram shows current at the beginning (at the opposite line end from TS Gumiipex) of the $20 \mathrm{kV}$ line which connects substation Gumiimpex with rest of the distribution system.

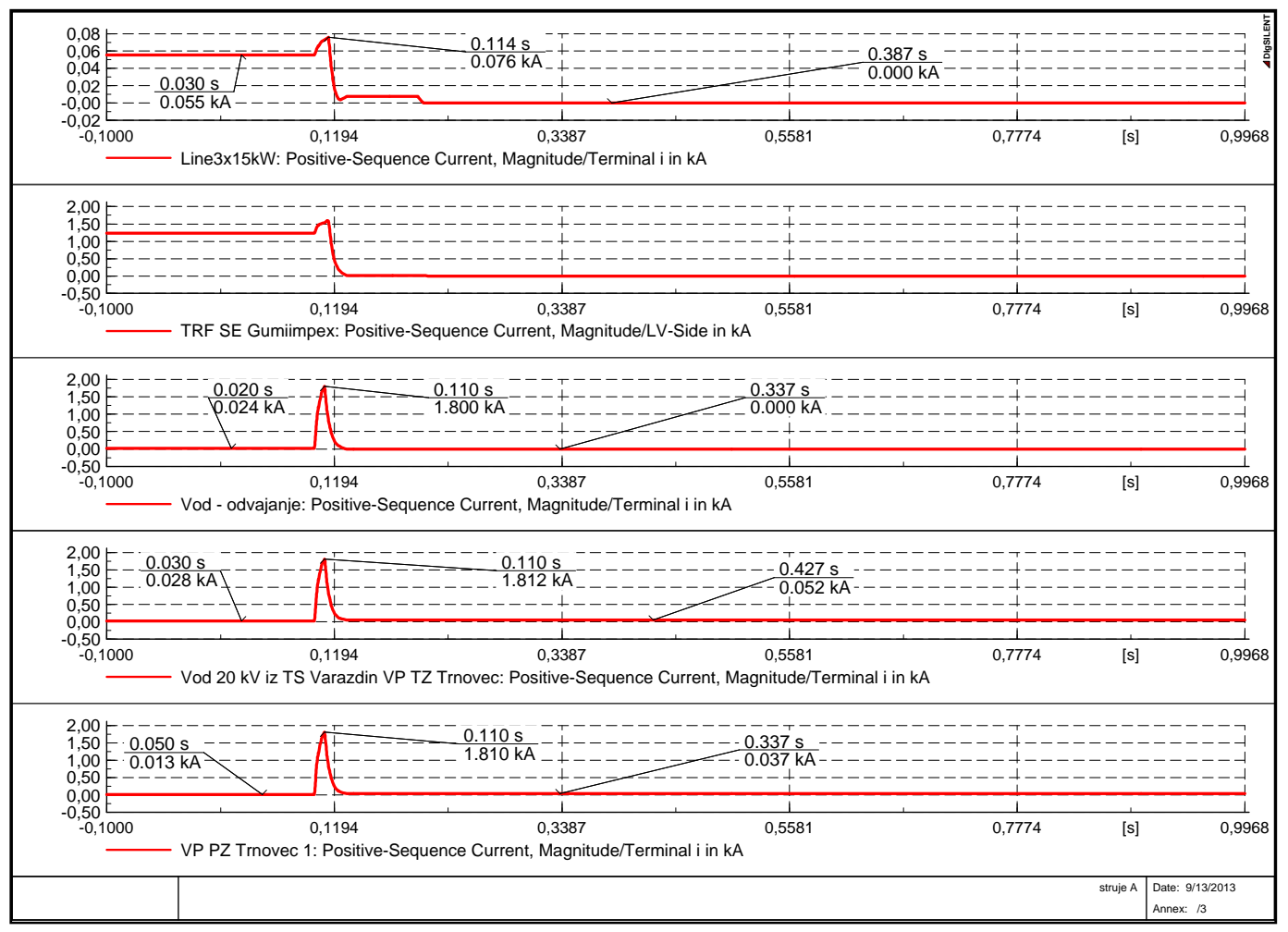

Figure 10. RMS values of currents during short circuit simulation for case SC2

Short-circuit protection (instantaneous overcurrent relay) located at the beginning (opposite from TS Gumiimpex) of the $20 \mathrm{kV}$ line which connects TS Gumiimpex 20/04 kV with rest of the distribution system tripped at time $\mathrm{t}=110 \mathrm{~ms}$. Thus, $20 \mathrm{kV}$ buses in TS Gumiimpex (fault location) are separated from the network. At the time $\mathrm{t}=114 \mathrm{~ms}$, overcurrent protection in TS Gumiimpex 20/0.4 kV tripped circuit breakers on $20 \mathrm{kV}$ side of the transformer and thus disconnected the PV power plant. Fast overvoltage protection $(\mathrm{V}>>)$ of inverters tripped at the time $\mathrm{t}=208 \mathrm{~ms}$.

Figure 11 shows the RMS values of voltages at the three locations close to PV power plant during a short circuit simulation. Upper diagram on the Figure 11 shows voltage at the inverters terminals. The second diagram shows the voltage at the $0.4 \mathrm{kV}$ side of the transformer Gumiimpex $20 / 0.4 \mathrm{kV}$. The last diagram shows voltage at the $20 \mathrm{kV}$ side of the transformer Gumiimpex $20 / 0.4 \mathrm{kV}$. 


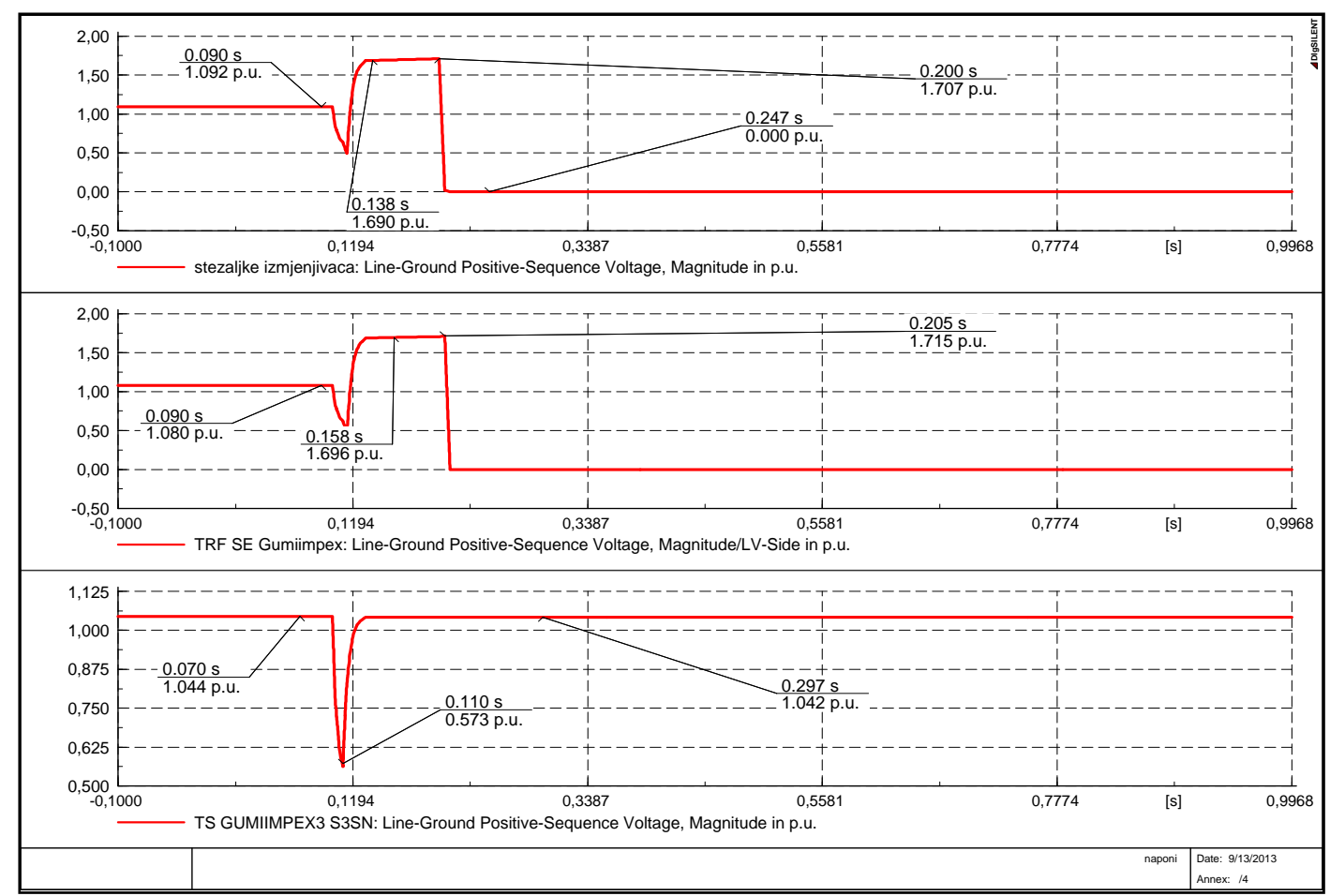

Figure 11. RMS values of voltages during short circuit simulation for case SC8

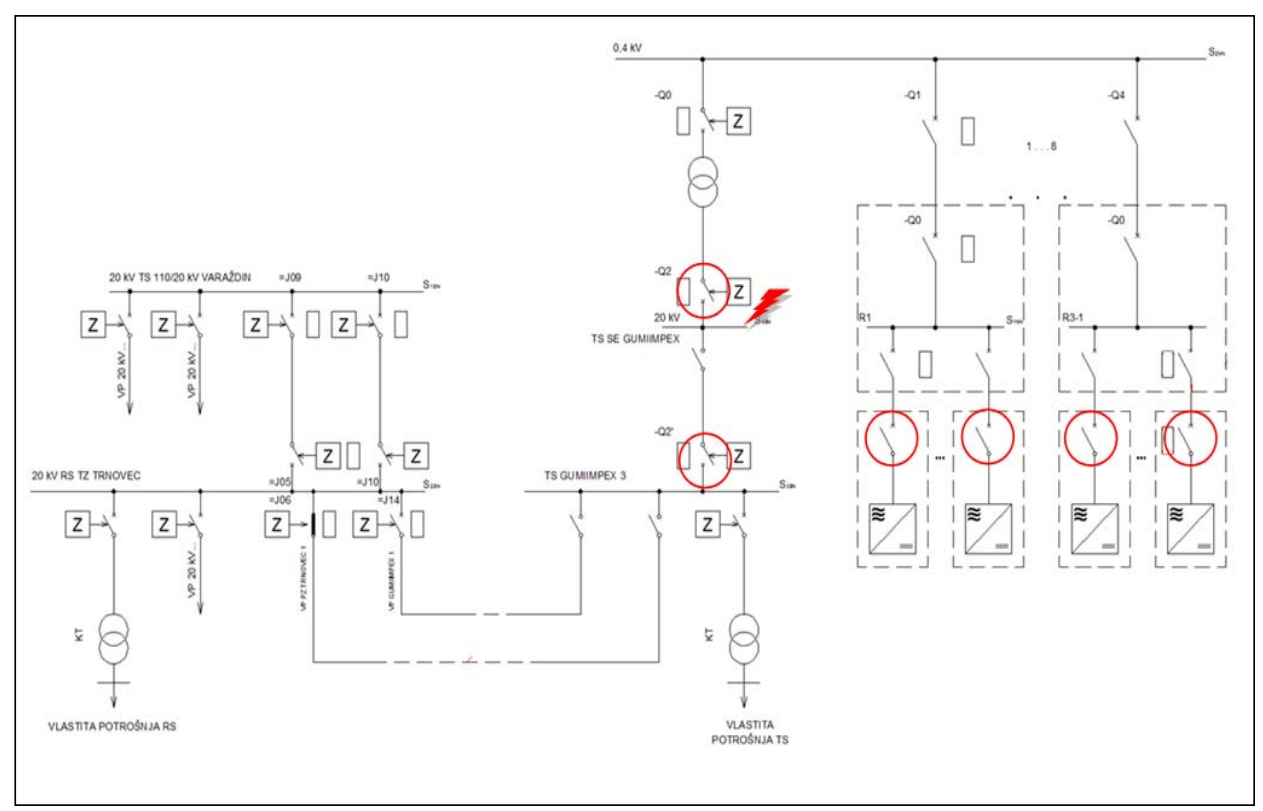

Figure 12. Single line diagram with tripped breakers for case SC2

SC3 - single line to ground short circuit at the $0.4 \mathrm{kV}$ bus in substation 20/0.4 TS Gumiimpex. Simulation starts at time $\mathrm{t}=0$ and short circuit occurs at time $\mathrm{t}=100 \mathrm{~ms}$. Type of simulated short circuit is single line to ground fault with fault impedance $=0 \Omega$. The location of fault is on the $0.4 \mathrm{kV}$ bus of the transformer Gumiimpex 20/04 kV (this transformer connects PV power plant with the network). Figure 13 shows the RMS values of currents which inverters of PV power plant feeds into the distribution network during a short circuit simulation. Upper diagram on the Figure 13 shows current of one group of inverters at 
the point where PV power plant is connected to the network $(0.4 \mathrm{kV}$ side of the transformer Gumiimpex $20 / 0.4 \mathrm{kV}$ ). The second diagram shows current that is flowing from the network at the $0.4 \mathrm{kV}$ side of the transformer Gumiimpex 20/0.4 kV. The third diagram shows current that is flowing from the network at the $20 \mathrm{kV}$ side of the transformer Gumiimpex 20/0.4 kV. And the last diagram shows the current at the beginning of the $20 \mathrm{kV}$ line in the $110 / 20 \mathrm{kV}$ transformer station Varaždin.

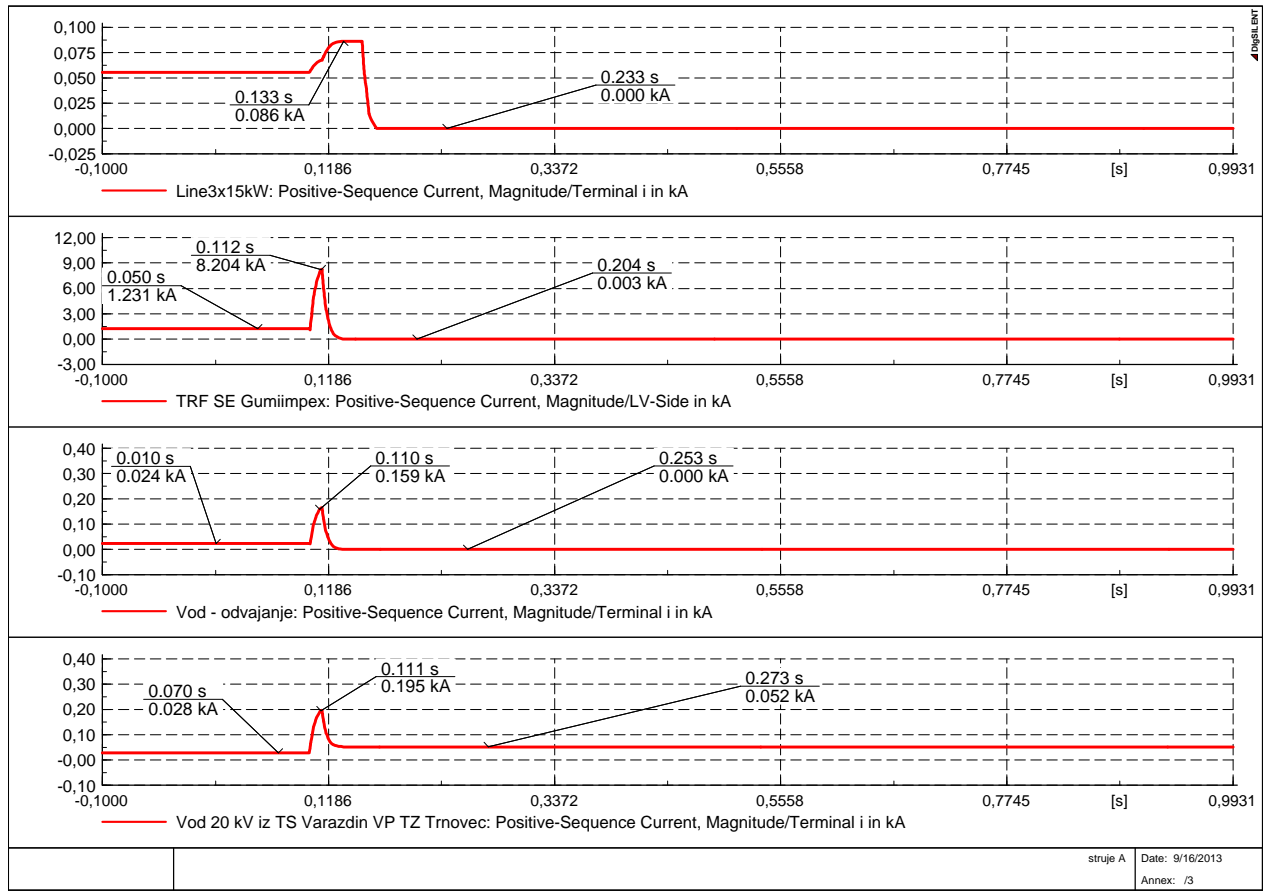

Figure 13. RMS values of currents during short circuit simulation for case SC3

Instantaneous earth-fault protection (relay Micrologic $6, \mathrm{I}_{0}>>=1200 \mathrm{~A}$ ) located at the LV side of the TS Gumiimpex tripped at time $\mathrm{t}=113 \mathrm{~ms}$. Thus, PV power plant is disconnected from the network. At the time $\mathrm{t}=204 \mathrm{~ms}$, fast overvoltage protection $(\mathrm{V}>>)$ of inverters tripped.

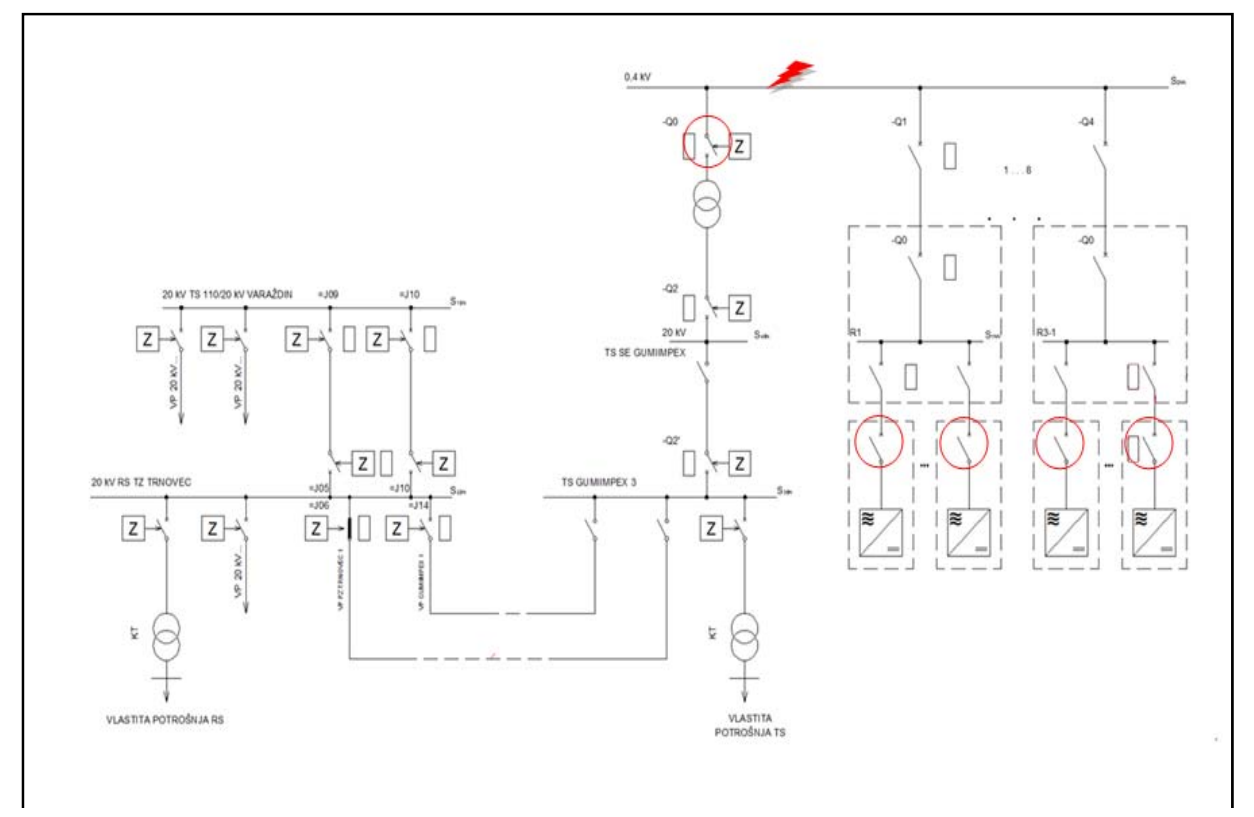

Figure 14. Single line diagram with tripped breakers for case SC3 
SC4 - single line to ground short circuit at the terminals of one of the inverters in PV plant Simulation starts at time $t=0$ and short circuit occurs at time $t=100 \mathrm{~ms}$. Type of simulated short circuit is single line to ground fault with fault impedance $R_{f}=0 \Omega$. The location of fault is at terminal of one of the inverters. Figure 15 shows the RMS values of currents which inverters of PV power plant feeds into the utility network during a short circuit simulation. Upper diagram on the Figure 16 shows current of faulted inverter. The second diagram shows the current of one selected inverter from the group that belongs to faulted inverter (affected group).

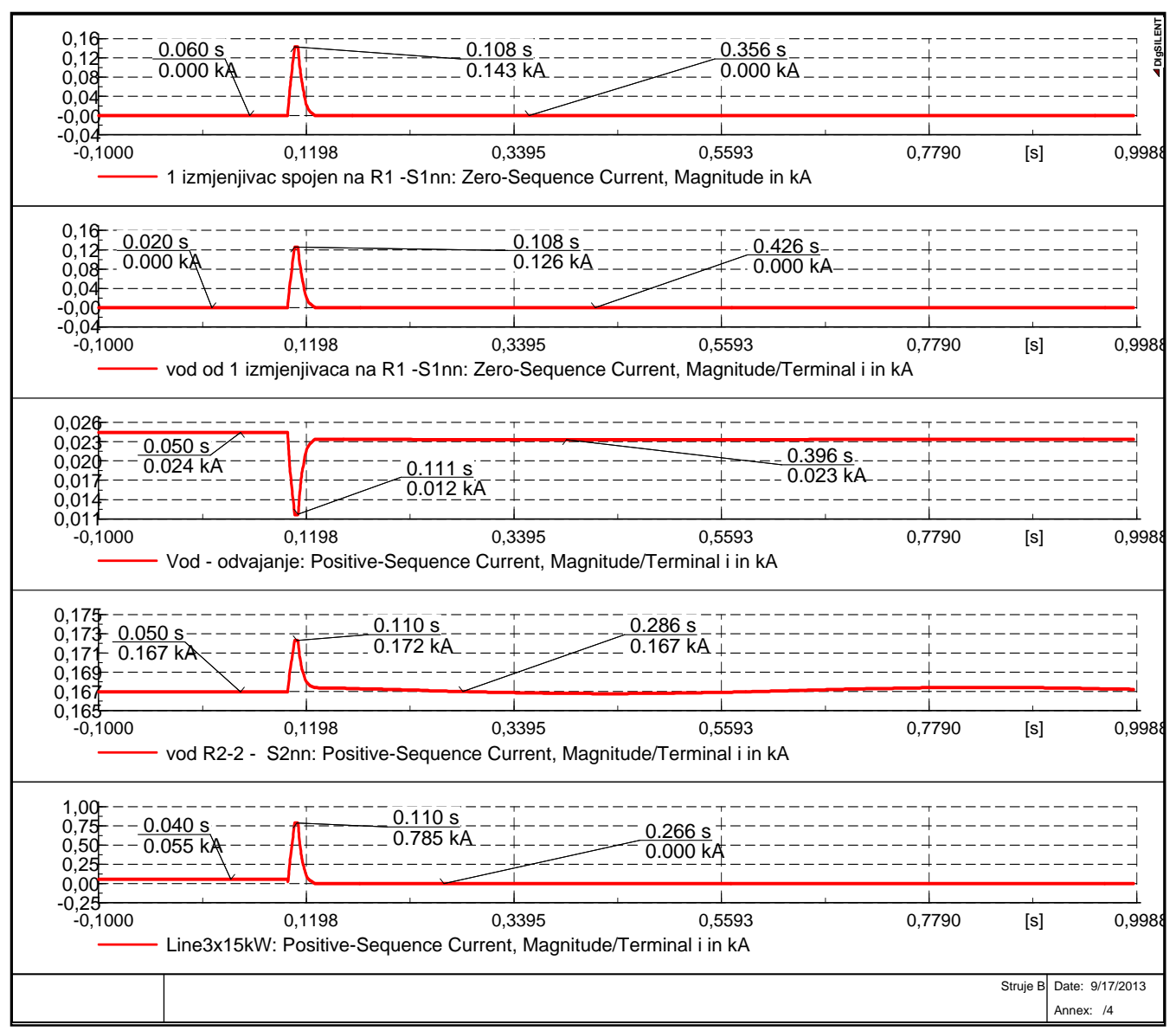

Figure 15. RMS values of currents during short circuit simulation for case 4

At the time $\mathrm{t}=110 \mathrm{~ms}$, fast overcurrent protection $(\mathrm{I}>>$ ) of affected group tripped. At the same time, automatic fuses of all inverters in the affected group tripped thus this group is disconnected.

Figure 16 shows the RMS values of voltages during a short circuit simulation. Upper diagram on the Figure 17 shows voltage at the faulted inverter terminals. The second diagram shows voltage at the terminals of the affected group of inverters. The third diagram shows the voltage at the $0.4 \mathrm{kV}$ side of the transformer Gumiimpex 20/0.4 kV. The last diagram shows voltage at the $20 \mathrm{kV}$ side of the transformer Gumiimpex $20 / 0.4 \mathrm{kV}$. 


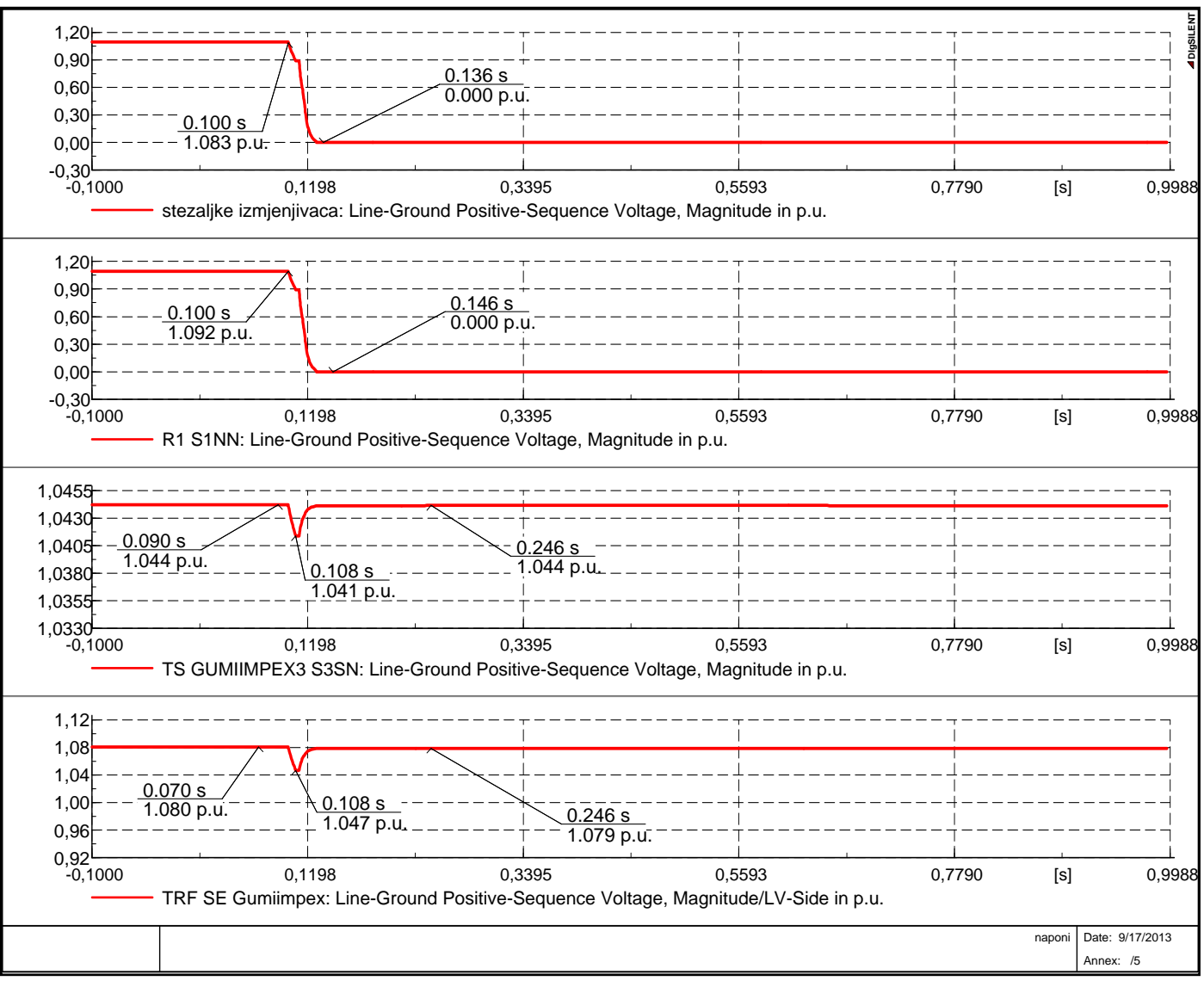

Figure 16. RMS values of voltages during short circuit simulation for case SC4

Figure 17 shows the single line diagram with marked breakers that tripped.

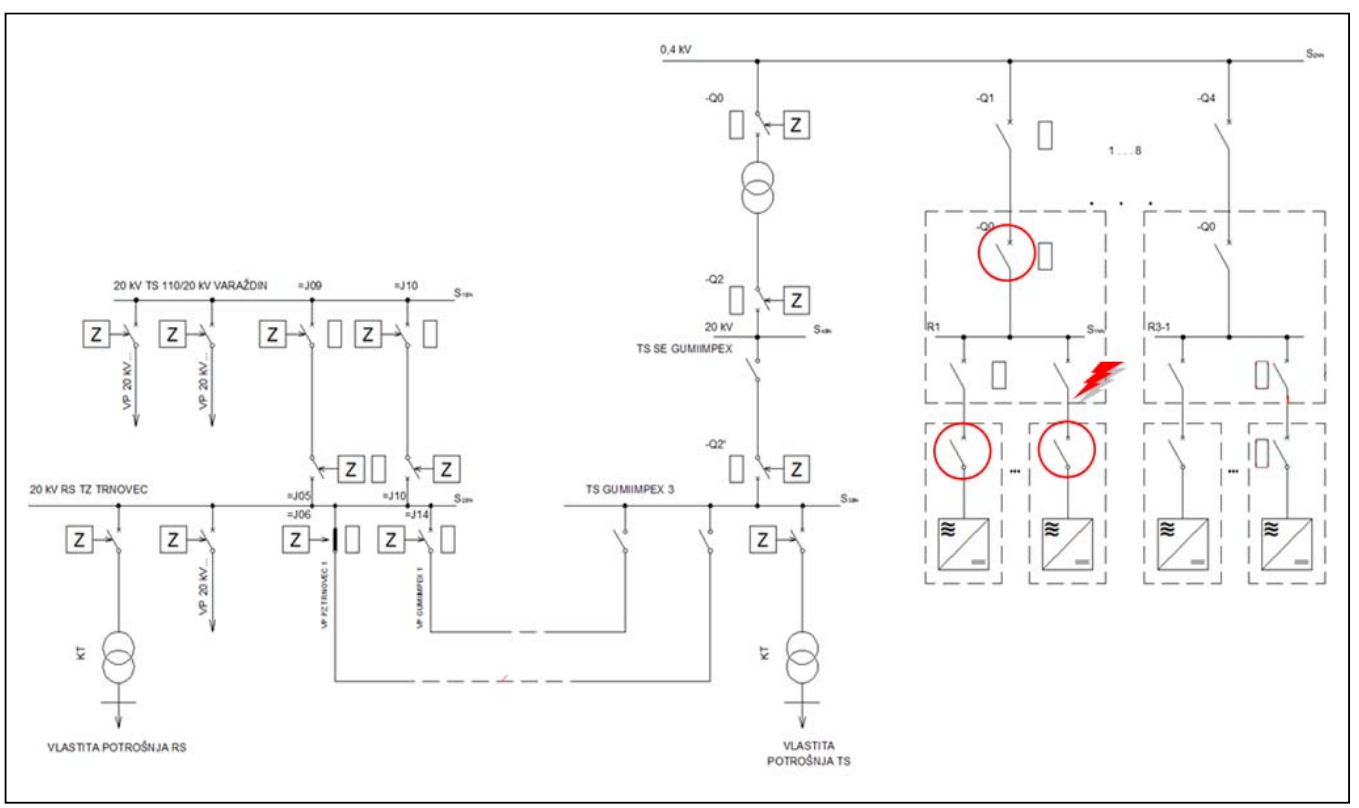

Figure 17. Single line diagram with tripped breakers for case SC4 
Time-current protection curves where obtained using EasyPower 9.7 software [8]. From Figure 18 can be seen that proposed time-current setting curves of different protection devices types and manufacturers (Schneider, Siemens, ABB, Schrack) are well set and have good time-current coordination from the first inverter to the last upstream devices on $20 \mathrm{kV}$ feeder.

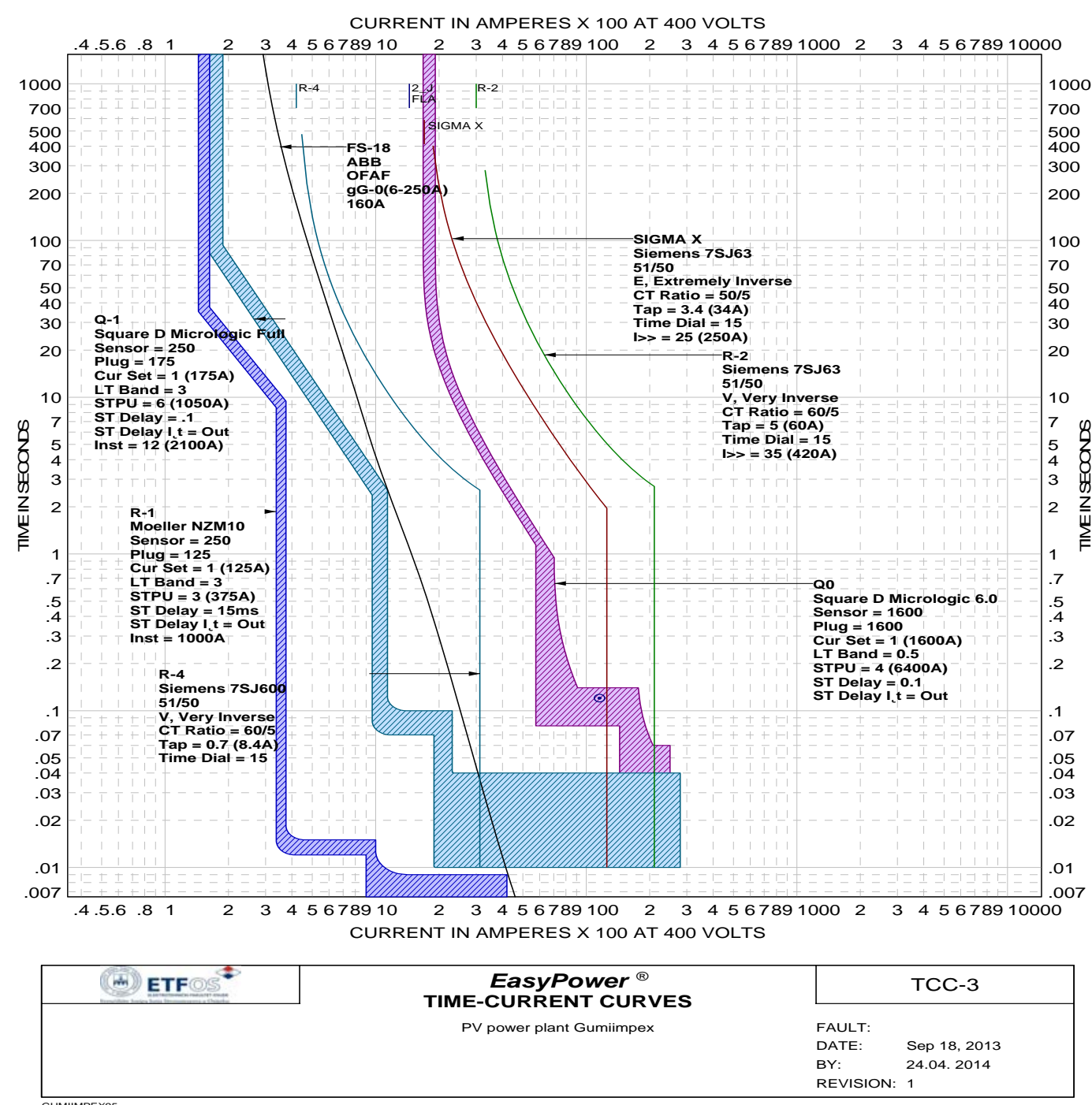

Figure 18. Time-current (t-I) characteristics of PV power plant and electrical network

\section{CONCLUSION}

This paper presents installed solar power plant SE Gumiimpex, rated power $1 \mathrm{MW}$ in Varaždin, in Croatia. Paper presents the results of power quality analysis at CCP between solar power plant and $20 \mathrm{kV}$ distribution network. Power quality indicators of supply voltage are measured seven days before and seven days after connection of solar power plant on the distribution network, according the Croatian national grid code and HRN EN 50160/2012 norm. Fault analysis and protection relays coordination was performed using DIgSILENT PowerFactory 14.1 software. Seventeen different places in the network and three different types of faults (Single Line to Ground fault, Line to Line fault and Three phase fault) where selected. Time variation of short circuit currents, voltages were presented during the fault conditions and relay tripping time was also presented and checked.

The time and current, voltage and frequency settings for all protection devices were well chosen. Some modifications and corrections for several relays were suggested. Solar power plant SE Gumiimpex satisfied all conditions and demands of HRN EN 50160/2012 norm and Croatian national grid code and is currently on distribution network. 


\section{REFERENCES}

[1] M.J. Ortega, at.al., "Measurement and assessment of power quality characteristics for photovoltaic systems: Harmonics, flicker, unbalance, and slow voltage variations", Electric Power Systems Research Journal, Volume 96, March 2013, Pages 23-35.

[2] A. Marinopoulos, at.al, "Grid integration aspects of large solar PV installations: LVRT capability and reactive power/voltage support requirements", Proceedings from IEEE PowerTech, 2011, conference, Trondheim, 19-23 June 2011, Pages 1-8.

[3] Y.C. Lern, at.al., "Overcurrent Protection Coordination for Solar Photovoltaic Plant Connected to Medium Voltage Distribution Network", 1st Annual International Conference on Power, Energy and Electrical Engineering -PEEE 2013, DOI: 10.5176/978-981-07-7531-5_PEEE.20.

[4] A.F.Nieim, at.al., "A Classification Technique for Protection Coordination Assessment of Distribution Systems with Distribution Generation", Proceedings of $14^{\text {th }}$ International Middle East Power System Conference -MEPCON 2010, December 19-21, 2010, Paper ID 190.

[5] HROTE website. [Online]. Available: http://www.hrote.hr/(2013).

[6] Voltage characteristic of electricity supply by public electric networks (EN 50160:2010), CENELEC Std. 2012.

[7] DIgSILENT Power Factory 14.1 User Manual, Gomaringen, 2013.

[8] EasyPower 9,7 version, User Maual, Easypower LCC,,Tulatin, USA,2014

[9] S. Nikolovski, at.al, "Simulation of Numerical Protection REF 541 in Transformer station TS 35/10 kV Using "Power Protector" Software", International Council on Large Electric System-CIGRÉ Croatian National Committee, VI Symposium, Vol. B5 - 17, Cavtat, Croatia, 2003, pp. 141-150

\section{BIOGRAPHIES OF AUTHORS}

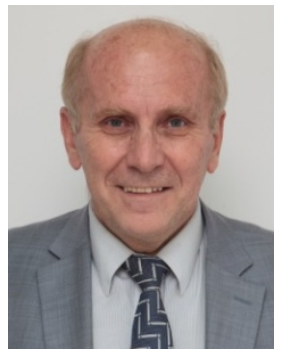

Srete Nikolovski, PhD.El.Eng. (IEEE M'1995, SM'2005) was born in Belgrade on October 1, 1954. He obtained his BSc degree (1978) and MSc degree (1989), in electrical engineering at the Faculty of Electrical Engineering, University of Belgrade and his PhD degree from the Faculty of Electrical and Computing Engineering, University of Zagreb, Croatia in 1993. Currently he is a Full Professor at Power Engineering Department at Faculty of Electrical Engineering, J.J. Strossmayer University in Osijek, Croatia. His main interests are power system protection, power system modeling, simulation and reliability. He has published over 180 technical papers in Journals and international conferences. He is a Senior Member of IEEE Reliability Society, PES Society, EMC Society and the member of Croatian National Committee of CIGRE

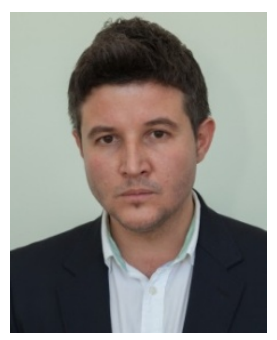

Predrag Marić, PhD.El.Eng, was born on 11 December 1979 in Osijek. He obtained diploma degree in 2004 in field of Electrical Power Engineering from the faculty of Electrical Engineering of Osijek. His graduation thesis awarded two prizes: "Hrvoje Požar" of Croatian Energy Institute as specially noticed thesis in field of power engineering, and a prize from Croatian Power Company HEP for the best graduation thesis in the field of power system reliability. Currently he works as assistant professor at the Power System Department at the Faculty of Electrical Engineering. Author of 19 scientific and professional work in the field og power system. His main interest is modeling, simulation and analysis of transient phenomena in power system. He IEEE member and member of Croatian National Committee of CIGRE.

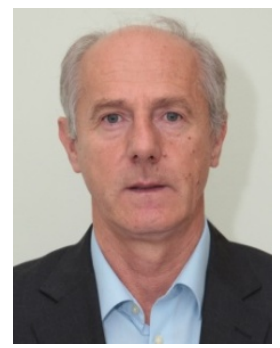

Ljubomir Majdnandžić PhD.Mech.Eng, was born on July 4, 1960 in Ivanjska at Banja Luka. He graduated two post studies: in 1999 at the Faculty of Mechanical Engineering and Naval Architecture University of Zagreb and in 2001 at the Faculty of Economics in Zagreb. From 2001 to 2003 working on a doctorate at the Fraunhofer Institute for Solar Energy, Department of electric power systems, in Freiburg, Germany. At the Faculty of Electrical Engineering and Computing in Zagreb his PhD in 2004. He is Associate Professor of Electrical Engineering, University of Osijek. Author of 64 scientific and professional work in the field of energy, renewable energy and sustainable development. He is a member of the International Solar Energy Society (ISES), the German Society for Solar Energy (Deutsche Gesellschaft für Sonnenenergie eV DGS) and the Croatian Energy Association (HED). 